\title{
Ayurvedic Intervention in the Management of Post-Operative Diabetic Foot Gangrene - A Case Study
}

\author{
Basavaraj Chanda ${ }^{1}$, Vislavath Srikanth ${ }^{2}$, Gopikrishna ${ }^{3}$, Prasanna N Rao ${ }^{4}$ \\ ${ }^{1,2}$ Post Graduate Scholar, ${ }^{3}$ Professor \& HOD, ${ }^{4}$ Professor \& Principal \\ ${ }^{1,3,4}$ Department of Shalya Tantra, ${ }^{2}$ Department of Rachana Sharir \\ Sri Dharmasthala Manjunatheshwara College of Ayurveda And Hospital, Hassan, Karnataka, India
}

\begin{abstract}
Surgical procedures normally carry a risk of wound infection, excessive bleeding or tissue damage. Diabetes has higher risk of wound healing complications following surgery. Wound tends to require more time to heal due to poor blood circulation, nerve damage, or a compromised immune system. In such conditions, non-healing wounds can lead to osteomyelitis, sepsis and even death also. Ayurvedic literature has given detailed explanations on wound management from its manifestation to the complete healing, shown good results in Non-healing wounds. Acharya Sushruta, explained Shodana (purification), Ropana (healing) procedures for wounds with Ayurvedic formulations includes Panchavalkala Kashaya and Jatyadi Taila. This is a case of 45-years old male, diabetic presented with the complains of non-healing wound on 5th right toe with swelling, discharge, foul smell and blackish discoloration of skin, diagnosed as diabetic foot gangrene. Ray's amputation done and post-operative wound management was carried under Ayurvedic treatment procedures. Significant improvement seen in wound healing within a short period. In this case Panchavalaka Kashaya and Jatyadi Taila show its Shodhana and Ropana properties.
\end{abstract}

KEY WORDS: Diabetes, Foot gangrene, Ayurvedic treatment, Panchavalkala Kashaya, Jatyadi Taila.

\section{INTRODUCTION}

Diabetic Mellitus is a chronic clinical syndrome characterised by hyperglycaemia, due to deficiency or defective response of insulin. It was estimated that approximately $1 \%$ of world population suffers from Diabetes. A consequence of hyperglycaemia of
Diabetes, every tissue and organ of body undergoes biochemical and structural alterations causes severe complications. A number of systemic complications may develop after a period of 15-20yrs. These late complications are largely responsible for morbidity and premature mortality. Diabetic foot ulcer is one of the infectious complication. ${ }^{[1]}$ In this slight injury to the glucose laden tissue may cause chronic infection and ulcer formation. Ulceration in diabetes may be precipitated by ischemia due to diabetic atherosclerosis, infection or peripheral neuritis. ${ }^{[2]}$

Diabetes is linked to gangrene, which occurs as a complication of a pre-existing health condition. Gangrene happened, when lack of oxygenated blood causes tissue to die in some parts of body, often the hand or feet. In these cases, patient, who have an injury may not notice the dead tissue infection due to diabetic neuropathy. It is a serious condition results in amputation of limb. ${ }^{[3]}$ Post-amputated wound management is serious problem in diabetic patients due to infection, wound becomes complicated and sometimes needs skin grafting. ${ }^{[4]}$

Ayurvedic literature has given detailed explanation regarding wound management starting from its pathogenesis, types, clinical features, complications and management. Acharya Sushruta mentioned the term Dushta Vrana which showed similar clinical features of the non-healing wounds according to present medical science. He explained 60 Upakramas(measures) for wound management from its manifestation to the complete healing, which shown good results in chronic wounds aka Dusta Vrana. ${ }^{[5]}$ 
The present case is diabetic foot gangrene which was amputated in SDM Hospital and post operative wound management carried under Ayurvedic wound treatment protocol.

\section{CASE REPORT}

This is a case of 45years old male, diabetic patient came to SDM Ayurvedic hospital with the chief complaints of - Blackish discoloration over the $5^{\text {th }}$ right little toe for 4 days.

Pain during pressure on toe,

Foul smell with watery discharge,

Swollen, reddish discoloration over the ulcer since 5days

Associated symptoms: General weakness, numbness in the hands and feet, Irregular constipation since 1month.

History of present illness: The patient had noticed blackish discoloration, pain during pressure at toe and foul smelling with watery discharge at $5^{\text {th }}$ right toe since 4-5days. The onset of symptoms was developed rapidly. Patient was not aware of changing in skin colour until pressure pain felt and noticed blackish discoloration on $5^{\text {th }}$ right toe. After that, he went to allopathic hospital and diagnosed with diabetic foot gangrene of $5^{\text {th }}$ right toe and suggested amputation by Diabetalogist. Patient refused and came to Ayurvedic hospital to seek conservative management.

\section{Past history}

He was known diabetic and on oral hypoglycaemic medications since 10 years, continued till today. He had previous history of amputation of $2^{\text {nd }}$ toe of right foot, done 1year back in allopathic hospital due to chronic non-healing ulcer.

\section{Personal history}

\begin{tabular}{|l|l|l|}
\hline \multicolumn{1}{|c|}{ Name :XYZ } & \multicolumn{1}{|c|}{$\begin{array}{c}\text { Bala: } \\
\text { Madhyama }\end{array}$} & $\begin{array}{c}\text { B.P: 130/88 } \\
\text { mm of Hg. }\end{array}$ \\
\hline Age:45years & $\begin{array}{l}\text { Sleep: Disturbed } \\
\text { due to pain }\end{array}$ & P.R: 68/min. \\
\hline Gender : Male & Appetite :Good & Weight:54kgs \\
\hline $\begin{array}{l}\text { Marital status } \\
\text { : Married }\end{array}$ & Bowel: Irregular & Height:5.7ft \\
\hline $\begin{array}{l}\text { Occupation: } \\
\text { Revenue } \\
\text { officer }\end{array}$ & Addictions : No & \\
\hline
\end{tabular}

\section{Systemic Examination: Not significant}

\section{Local Examination:}

Site $\quad-$ over $5^{\text {th }}$ right toe

Size - Length: $2.5 \mathrm{~cm}$, Width: $1.6 \mathrm{~cm}$

Number $\quad: 1$

Edge and margin -Inflamed with irregular border

Floor

: Covered with slough and unhealthy granulation tissue

Base : Indurated

Discharge : blood stained pus discharge with foul smelling - on and off

Surroundings : Blackish in colour

Bleeding (-)

Tenderness : Present

Regional Lymph node : Not palpable.

Rogaadhishtanam: Adhahkayam (Twak, Mamsam, Asthi, Sira)

Avastha : Pakwam.

Provisional diagnosis: Dushta Vranam.

Clinical diagnosis: Dushta Vranam (diabetic foot

gangrene)

Prognosis : Krichra Sadhyam.

\section{Examination of Gangrene:}

Symptoms such as claudication and rest pain are present.

\section{Inspection:}

Change in colour : Blackish in colour

Extension

: Up to metatarsal

Signs of ischemia : Thinning of skin noted

Loss of subcutaneous fat

Trophic changes in nails such as-brittle nail with transverse ridges noted.

Burger's Angle was $>60^{\circ}$.

\section{Palpation:}

Skin temperature-cold

Capillary filling test-slow

Venous refilling time- $12 \mathrm{sec}$

Fuching test-negative, normal popliteal artery pulsation felt with oscillatory movements of foot.

\section{TREATMENT}

After careful examination and clinical findings, it is diagnosed as Dushta Vrana [gangrene wound] and patient admitted in surgical word of SDM hospital. A thorough counselling was done to the patient regarding severity of wound and future complications of gangrene. After consent of patient, Ray's 
amputation procedure was performed on $5^{\text {th }}$ right toe. Healing of amputated wound in diabetic patient is major challenge in practice. Patient has similar history of delayed wound healing during $2^{\text {nd }}$ right toe amputation, which took 4 months to heal. The postamputated wound was treated under Sushruta's Dushta Vrana management protocol. Based on need we performed Chedana, Bhedana, Shodana and Ropana measures from Sushruta's 60 Upakramas for this case. The management of amputated wound protocol summarized in table no.1. At the end of 2 nd month wound healed completely without need of skin grafting with minimal scar formation. The details of treatment are explained in discussion.

Table No.1: Chronology of Treatment Protocol

\begin{tabular}{|c|c|c|}
\hline $\begin{array}{l}\text { Type of } \\
\text { treatment }\end{array}$ & From-to & Intervention \\
\hline Local & $\begin{array}{l}2.1 .2018 \text { to } \\
12.1 .2018\end{array}$ & $\begin{array}{l}\text { Panchavalkala } \\
\text { Qwatha to wash } \\
\text { wound }\end{array}$ \\
\hline Local & $\begin{array}{l}5.1 .2018 \text { to } \\
15.2 .2018\end{array}$ & $\begin{array}{l}\text { Applied Jatyadi } \\
\text { Taila over the wound }\end{array}$ \\
\hline $\begin{array}{l}\text { Systemic } \\
\text { treatment }\end{array}$ & $\begin{array}{l}\text { 2.1.2018 to } \\
\text { 16.1.2018 } \\
\text { Then again on } \\
2.2 .2018 \text { to } \\
16.3 .2018\end{array}$ & $\begin{array}{l}\text { Tab Gandhak } \\
\text { Rasayana } 500 \mathrm{mg} 2 \mathrm{~d} \\
\text { BD Rese }\end{array}$ \\
\hline & $\begin{array}{l}2.1 .2018 \text { to } \\
2.2 .2018\end{array}$ & $\begin{array}{l}\text { Triphala Guggulu Ve } \\
250 \mathrm{mg} \mathrm{BD}\end{array}$ \\
\hline
\end{tabular}

\section{Local treatment}

The wound was washed with the decoction of Panchavalkala Kashaya daily, which was made up of barks of Vata (Ficus bengalensis Linn), Udumbara (Ficus glomerata Roxb.), Ashwatha (Ficus religiosa Linn.), Parisha (Thespesia populenea Soland ex corea.) and Plaksha (Ficus lacor Buch-Ham). After washing the wound dried, then by aseptic technique Jatyadi Taila was applied daily up to complete heal.

\section{Systemic treatment}

Depending on symptoms and for better healing of wound following medications were given orally.

$>$ Tab Gandhak Rasayana 500 mg 2 BD for 15 days with 15 days gap, repeated twice.

$>$ Triphala Guggulu $250 \mathrm{mg}$ BD for 1 month

\section{Follow up advices}

Advice to review every 7 days

Pathya: Shali, Patolam, Karavellaka, Amalaki.
Apathyam: Masha, sour and salty food, curd, oily and spicy foods and day sleep are adviced to avoid.

\section{OBSERVATION AND RESULT}

Healthy granulation tissue was formed within one week. Washing of the wound was continued with Panchavalkala Kashaya till the end as mentioned above. Healthy granulation tissue was observed after 10 days. The wound started to contract by filling of tissue from the base of wound day by day. The Jatyadi Taila dressing was continued till complete healing. on 31 st day, it was observed that wound size was markedly reduced with normal skin coloration at the healed area. On the 50th day, the wound was healed completely with minimum scar tissue formation. It is observed that patient's associated symptoms also reduced markedly.

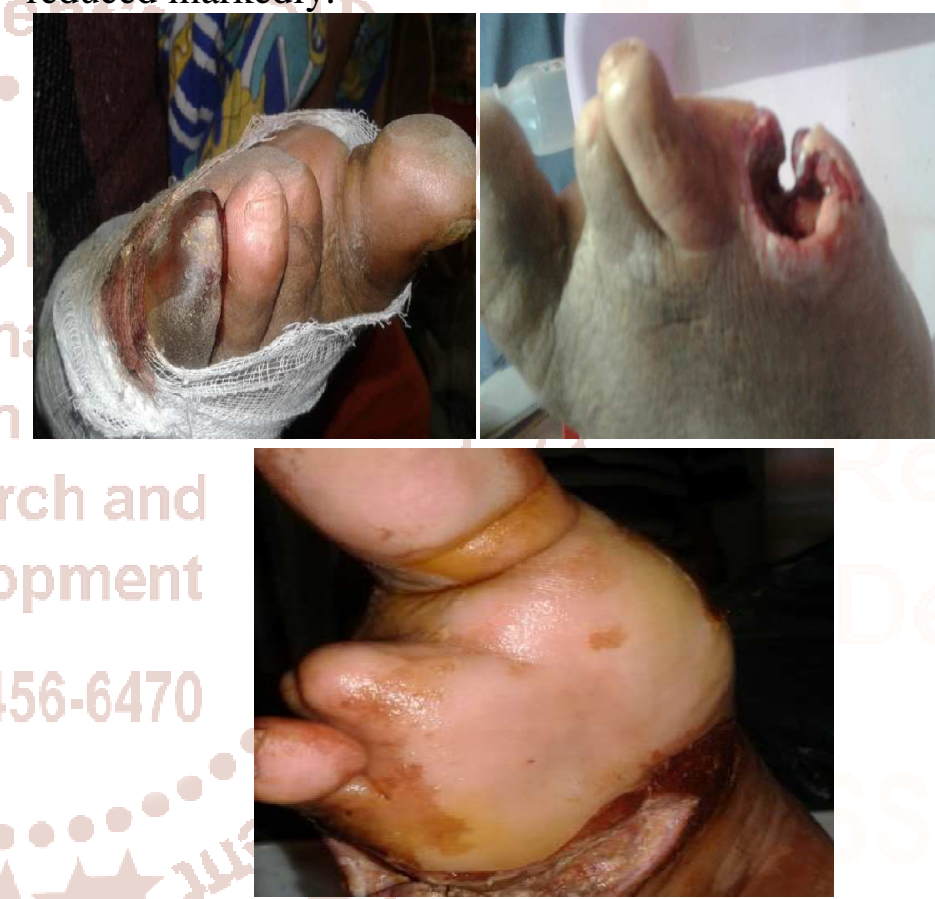

Figure 1: Diabetic foot gangrene before treatment

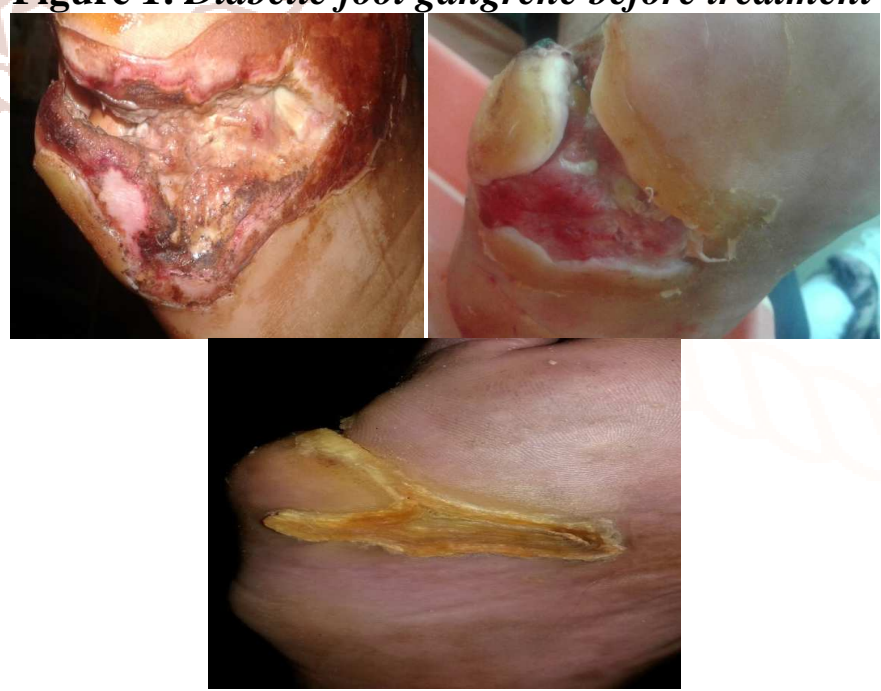

Figure2: Diabetic foot gangrene after treatment 


\section{DISCUSSION}

Diabetic foot ulcers (DFU) are a fairly common complication of Diabetes mellitus. These are two forms: Neuropathic ulcers and Ischemic ulcers, although most DFUs are a mixture of both. Neuropathic Diabetic Foot Ulcer is because of high blood sugar levels damaging the nerves known as peripheral neuropathy. As the incidence of Diabetes mellitus is increasing globally, increase in complications is also unquestionable. Overall $15 \%$ of individuals with Diabetes mellitus will have foot ulcer during their lifetime and the annual incidence is $2-3 \%$. The general line of treatment includes antibiotics to treat infections, revascularisation if associated with ischemia, to improve the condition of the wound or ulcer by wound-bed preparation, topical applications, and removal of callus. Amputation is the last option for complicated wounds. ${ }^{[6]}$ Foot gangrene is a frequent complication in diabetes mellitus. It results from various factors such as atherosclerosis, neuropathy, infection and angiopathy. ${ }^{[7]}$ Gangrene happened, when lack of oxygenated blood to the tissue in some parts of body, often the hand or feet. In these cases, patients who have an injury may not notice the dead tissue infection due to Diabetic neuropathy. It is a serious condition results in amputation of limb ${ }^{[8]}$ As with any surgery, an amputation carries a risk of complications. Such as Wounds infection, Pain, Muscle weakness, contractures and Autonomic dysfunction. The frequent symptom is Oedema. Foot amputation in Diabetes, have challenging problem of healing in surgical practice. ${ }^{[9]}$

In Ayurvedic science, the comprehensive management of all Vrana(wounds/ulcer) were exclusively described by Acharya Sushruta under Shashti Upakrama (sixty procedures). He has explained wound from its different aspects right from the definition, causes, types and their management in detail. While describing the types of Vrana, mentioned the term Dushta Vrana which is having similar clinical features of chronic non-healing wounds according to present medical science. In the Vrana management along with Upakrama, lot of medications in different formulations for wound healing were explained. ${ }^{[10]}$ The sixty measures are for wound management are incorporated in Sapta Vidha Upakrama. These 7 main procedures are carried when swelling of wound present. Vimlapana is done with thumb or bamboo reeds, i.e. local application of pressure. Avasechana done with Jalouka (leeches),
Sringa, Alabu or Shastra, i.e. removing impure blood from wound. Upanaha done with poultice to induce paka of wound. Patana is a surgical or para surgical procedure used to remove slough from wound. Shodhana is one of the important procedures in wound management. Wound cleaning is done with medicated decoctions, paste, medicated ghee, oil etc. Ropana procedure done for wound healing. Medicated oil or ghee or honey or medicated churna used as dressing in ropana, usually done after shodana. Vaikrutapaha used after wound healing, known as cosmetic treatment do for the getting normal skin colour with hair growth. ${ }^{[11]}$

In the present study, we used Patana Karma to do amputation of $5^{\text {th }}$ right toe. Shodana with Panchavalkala Kashaya and Ropana with Jatyadi Taila carried till the end of healing. Based on symptoms like constipation, skin itching and to control infection Triphala Guggulu and Gandhaka Rasayana given orally and healing of wound achieved within a short period.

\section{ROLE OF PANCHAVALKALA KASHAYA}

Panchavalkala is one of the ideal combinations for a vast range of therapeutics focused in Ayurveda like Vranaropana, Shothahara, Graahi, Visarpahara etc. It was prepared with barks of five trees viz. Vata (Ficus bengalensis Linn), Udumbara (Ficus glomerata Roxb.), Ashwatha (Ficus religiosa Linn.), Parisha (Thespesia populenea Soland ex corea.) and Plaksha (Ficus lacor Buch-Ham.). Researchers in recent and past evaluated that The barks of these plants contain anti-inflammatory, anti-bacterial and healing properties due to the presence of Tannin, Silica and phosphorus. ${ }^{[12]}$ Extraction of barks of these plants reduced blood sugar in normal as well as in alloxan induced diabetic rabbits ${ }^{[13]}$ and hypoglycaemic activity seen in albino rats. ${ }^{[14]}$

\section{ROLE OF JATYADI TAILA}

The wound dressing was done with Jatyadi Taila formulation, which has good Shodhana (cleansing) and Ropana (healing) properties as per Ayurvedic classics. This Traditional oil-based formulation acts as antiseptic, fungicidal and a good healer used in boils, cuts, wounds, burns, piles \& fistula. Jatyadi Taila of SDM Pharmacy (udupi), Karnataka, India was used.

Jatyadi Taila ingredients: Jati - Myristica fragrans; Nimba - Neem - Azardirachta indica; Patola Stereospermum suaveolens; Naktamala - leaves of 
Pongamia pinnata; Sikta - Honey bee wax; Madhuka - Licorice - Glycyrrhiza glabra; Kushta - Saussurea lappa; Haridra - Turmeric - Curcuma longa; Daruharidra - Berberis aristata; Manjishta - Rubia cordifolia; Katurohini - Picrorhiza kurroa; PadmakaPrunus puddum; Lodhra - Symplocos racemosa; Abhaya - Terminalia chebula; Nilotpala - Nymphaea stellata; Tutthaka - Copper sulphate; Sariva Hemidesmus indicus; Naktamala beeja - Seeds of Pongamia pinnata; Taila \& Water. ${ }^{[15,16]}$ All of these dravyas(drugs) have anti- bacterial, anti-slough properties and the combined effect of all of them facilitated wound healing by improving granulation tissue. Nimba bark extract produced significant antiinflammatory activity, aqueous extract of leaves decreased blood sugar in dogs. ${ }^{[17]}$ Haridra has antibacterial activity against gram-positive and gramnegative organism and anti-inflammatory activity. ${ }^{[18]}$ The leaf juice of Jati plant showed antibacterial activity against Staphylococcus Aureus. ${ }^{[19]}$

\section{ROLE OF GANDHAKA RASAYANA}

Gandhaka Rasayana is broad spectrum Ayurvedic antibiotic, anti-microbial, anti-inflammatory and is blood purifier also. The ingredients used in this formulation are Gandhaka(sulphur), re Twak (Cinnamomum zeylanicum), Ela (Elettaria cardmomum), Tejpatra (Cinnamomum tamala), Nagakeshar (Mesua farrea), Guduchi (Tinospora cordifolia), Haritaki (Terminalia chebula), Amalaki (Phyllanthus emblica), Bibhitaki (Terminlia bellirica), Bhringaraja (Eclipta alba) and Ardraka (Zingiber officinale). A study was done for screening of antibacterial and antifungal activity of Gandhaka Rasayana. Its in-vitro antifungal and antibacterial activity was found that Gandhaka Rasayana solution in different concentrations showed a significant zone of inhibition against three strains of bacteria and four strains of fungi. As per classics, it acts on blood and skin. It removes toxicity from blood and promotes wound healing by controlling infection. Gandhaka Rasayana has known hepatotoxicity, therefore it cannot be given for longer period. ${ }^{[20]}$

\section{ROLE OF TRIPHALA GUGGULU}

It is a popular safe and effective formulation for mitigation of Tridosha, mainly Vatadosha. It was indicated in Shota (inflammation), haemorrhoids and in fistula treatment.

Contents of Triphala Guggulu are- Haritaki, (Terminalia chebula) Bibhitaki, (Terminala belerica)
Amalaki, (Emblica officinalis) Pippali, (Piper longum) Suddha Guggulu (Commiphora mukul). ${ }^{[21]}$ Components of Triphala Guggulu showed antibacterial activity in invitro studies against gram positive and gram negative organisms. Haritaki, Amalaki found to possess hypoglycaemic activity on glucose-induced hyperglycaemia in rats. Amalaki has found potent antibacterial activity along with antiinflammatory activity and anti-atherosclerotic activity. ${ }^{[22]}$

\section{CONCLUSION}

Foot gangrene is a frequent complication in Diabetes mellitus. It results from various factors such as atherosclerosis, neuropathy, infection and angiopathy. The present case diagnosed as diabetic foot gangrene and after amputation of toe post-operative wound management carried under Ayurveda treatment.

Shodhana and Ropana Karma carried with Panchavalkala Kashaya and Jatyadi Taila, showed significant improvement in wound healing.

\section{REFERENCES}

1. Mohan H, Text Book of Pathology, $4^{\text {th }}$ ed, New Delhi: Jaypee Brothers medical publishers (pvt) Limited; 2010, p802-808

2. Ajith A, "Role of Aragwada Avachoornana in the management of Dushta Vrana" Master's dissertation, Rajiv Gandhi University of health sciences, Bengaluru, 2015, p34

3. https://www.medicalnewstoday.com/articles/1587 70.php

4. Soni1 S, Avinash Markam A, Singh B et al, A review literature on Dushta Vrana, European Journal of Biomedical and Pharmaceutical Sciences;2017, 4(7):p252-254

5. Kumar A, Kumar RG, Dutt VS, Ayurvedic perspective of Dusta Vrana (non-healing ulcer), International Ayurvedic Medical Journal; 2016Januar, Volume 4(02):p51-55

6. Saha A, Halder S, Giri KN, Diabetic foot ulcers: identification, diagnosis and cure, International Journal of Ayurveda and Pharma Research; 2015 December, Vol 3(12):p33-38

7. Oriani G, Meazza D, Favales F, et al,Hyperbaric oxygen in diabetic gangrene, J Hyperb Med; 1990,Vol 5:p171-5

8. https://www.medicalnewstoday.com/articles/1587 70.php 
9. Mcintosh J, Earnshaw J J, Antibiotic Prophylaxis for the Prevention of Infection after Major Limb Amputation, European Journal of Vascular and Endovascular Surgery; 2009, Vol 37(6): p696-703

10. Kumar A, Kumar RG, Dutt VS,Ayurvedic perspective of Dusta Vrana (non-healing ulcer), International Ayurvedic Medical Journal; 2016January, Volume 4(02):p51-55

11. Acharya YT, Sushruta Samhita of Sushruta, Sutra Sthana, Ch.17, Ver.17. 8th ed. varanasi: Chaukamaba publications; 2006.p84.

12. 12.Khadkutkar D, Kanthi GV, Tukaram D, Antimicrobial Activity of Panchavalkal Powder and Ointment, International Journal of Medicinal Plants and Natural Products; 2016, Vol2 (1): p915

13. Sastry JLN, Dravyaguna Vijnana, $2^{\text {nd }}$ ed, Varanasi: Chaukhambha orientalia; 2005, p501

14. Sastry JLN, Dravyaguna Vijnana, $2^{\text {nd }}$ ed, Varanasi: Chaukhambha orientalia; 2005, p945

15. Anantramram Sharma, Sushruta Samhita of Sushruta, Chikitsastan Sthana, Vol-2, Ch.31, Ver.06, varanasi: Chaukamaba publications; 2001.p407
16. Priti DP, Simpy R, Nargis KI, et al, Burn Wound Healing Potential of Jatyadi Formulations in Rats, Research Journal of Pharmaceutical, Biological and Chemical Sciences;2012, Vol 3(4): p747-754.

17. Sastry JLN, Dravyaguna Vijnana, $2^{\text {nd }}$ ed, Varanasi: Chaukhambha orientalia; 2005, p126

18. Sastry JLN, Dravyaguna Vijnana, $2^{\text {nd }}$ ed, Varanasi: Chaukhambha orientalia; 2005, p515

19. Sastry JLN, Dravyaguna Vijnana, $2^{\text {nd }}$ ed, Varanasi: Chaukhambha Orientalia; 2005, p834

20. Asore GR, Sheth SS, Shinde SB, Critical review of Gandhak Rasayana with special reference to Tvachavikara, International Research Journal of Integrated Medicine \& Surgery; 2017, Vol 4(1): p37-39.

21. Gandhi TN, Gupta SN, Patel MV et al, Pharmacuetico-analytical study of Triphala guggulu, Journal of Ayurveda and integrated medical scienes; 2017, Vol 2(5): p67-71

22. Sastry JLN, Dravyaguna Vijnana, $2^{\text {nd }}$ ed, Varanasi: Chaukhambha orientalia; 2005, p210224. 